\title{
Effects of Mineral Fibers on the Gene Expression of Proinflammatory Cytokines and Inducible Nitric-Oxide Synthase in Alveolar Macrophages
}

\author{
Yasuo MORIMOTO ${ }^{1 *}$, Tohru TSUDA ${ }^{1}$, Masami HIROHASHI ${ }^{1}$, Hiroshi YAMATO ${ }^{1}$, \\ Hajime HORI ${ }^{2}$, Akira OHGAMI', Kazuhiro YATERA ${ }^{3}$, Heung-Nam KIM', \\ Li DING ${ }^{1}$, Masamitsu KIDO ${ }^{3}$, Toshiaki HIGASHI ${ }^{1}$ and Isamu TANAKA ${ }^{1}$ \\ ${ }^{1}$ Institute of Industrial Ecological Sciences, \\ ${ }^{2}$ School of Health Sciences \\ ${ }^{3}$ Division of Respiratory Disease, University of Occupational and Environmental Health, 1-1 Iseigaoka, \\ Yahatanishiku, Kitakyushu 807-8555, Japan
}

Received January 11, 1999 and accepted April 12, 1999

\begin{abstract}
To determine which parameters are useful for the risk assessment of man-made mineral fibers (MMMFs), we examined the gene expression of interleukin-1 $\alpha$ (IL-1 $\alpha$ ), tumor necrosis factor $\alpha(\mathrm{TNF} \alpha)$, interleukin-6 (IL-6) and inducible nitric-oxide synthase (iNOS) in mineral fiber-exposed alveolar macrophages (AMs). Male Wistar rats were intratracheally exposed to saline or mineral fibers suspended in saline ( $2 \mathrm{mg}$ of crocidolite, chrysotile, alumina silicate refractory fiber (RF1) or potassium octatitanate whisker (TW)). Bronchoalveolar lavage was performed 4 weeks after the fiber-instillation, and the recovered AMs were stimulated by lipopolysaccharide for 2 or 6 hours. Expression of IL-1 $\alpha$, TNF $\alpha$, IL-6 and iNOS from AMs was observed using reverse transcription polymerase chain reaction (RT-PCR). The levels of IL-1 $\alpha$ and IL-6 mRNA induced by mineral fiber exposure were greatest in AMs exposed to TW, crocidolite, chrysotile and RF1 in that order. However, both gene expression of iNOS and TNF $\alpha$ were not elevated in both crocidolite and TW exposure, despite their high pathological potential. These data suggested that IL-1 $\alpha$ and IL-6 may be useful indicators for the risk assessment of MMMFs.
\end{abstract}

Key words: Man-made mineral fiber, Asbestos, Risk assessment, RT-PCR, Cytokine

\section{Introduction}

Occupational and environmental exposure to asbestos causes pulmonary fibrosis, bronchogenic carcinoma and pleural mesothelioma ${ }^{1)}$. Recently, various types of manmade mineral fibers (MMMFs) have been developed as substitutes for asbestos, and the demand for these products is increasing. Some of these fibers may possess the same adverse biological effects as asbestos because of their similar physiochemical properties ${ }^{2)}$.

*To whom correspondence should be addressed.
Figure 1 shows lung remodeling induced by mineral fibers. Mineral fibers deposited in the lung are phagocytosed by alveolar macrophages (AMs). AMs and parenchymal cells release tumor necrosis factor $\alpha$ (TNF $\alpha$ ), interleukin- $1 \alpha$ (IL$1 \alpha$ ), interleukin-6 (IL-6), and other chemokines which augment the process of inflammation. Then, these inflammatory cells release oxidants including nitric oxide, which may cause lung injury through inducible nitric oxide synthase (iNOS). Some growth factors signal fibroblasts to proliferate and modulate their production of connective tissue proteins, especially collagen ${ }^{3,4)}$. The accumulation of inflammatory cells and fibroblasts, and the development 


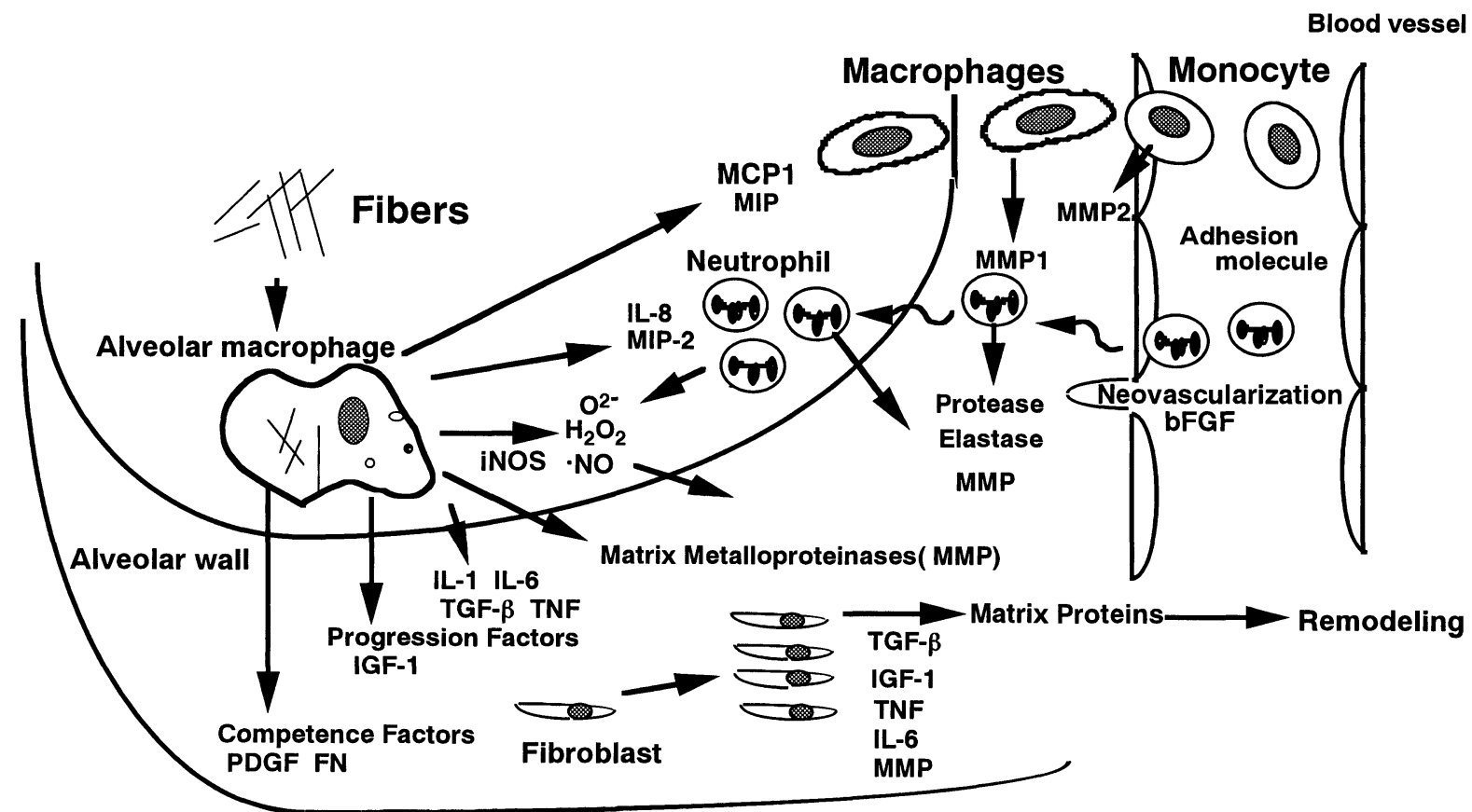

Fig. 1. Factors concerning a lung remodeling induced by mineral fibers.

Table 1. Dimension of mineral fibers

\begin{tabular}{lcccc}
\hline & Crocidolite & Chrysotile B & TW & RF1 \\
\hline Geometric mean diameter $(\mu \mathrm{m})$ & $0.33 \pm 2.1$ & $0.15 \pm 1.8$ & $0.41 \pm 1.5$ & $0.77 \pm 2.53$ \\
Geometric mean length $(\mu \mathrm{m})$ & $2.5 \pm 2.0$ & $2.6 \pm 2.3$ & $2.8 \pm 2.0$ & $12.0 \pm 2.36$ \\
\hline
\end{tabular}

Results are expressed as the mean \pm SEM. TW; potassium octatitanate whisker, RF1; alumina silicate ceramic fibers.

of connective tissue matrices leads to pulmonary fibrosis and carcinoma ${ }^{4}$.

We previously reported the gene expression of proinflammatory cytokines, growth factors, manganese superoxide dismutase (MnSOD) and inducible nitric oxide synthase (iNOS) in rats exposed to asbestos and some MMMFs. In that study, mineral fiber-exposure increased the gene expression of IL- $1 \alpha$, TNF $\alpha$, IL- 6 and iNOS in rats $\mathrm{AMs}^{3)}$.

To investigate which factors correspond to pathological potentials of mineral fibers, we examined the gene expression of IL- $1 \alpha$, TNF $\alpha$, IL- 6 and iNOS mRNA in rat AMs following exposure to four mineral fibers using reverse transcription - polymerase chain reaction (RT-PCR).

\section{Materials and Methods}

\section{Fiber preparation}

The mineral fibers used in this study were: UICC crocidolite asbestos (crocidolite), UICC chrysotile B asbestos (chrysotile), potassium octatitanate whisker (TW) and alumina silicate refractory fibers (RF1). RF1 was distributed by Japan Fibrous Material Research Association as their standard fibrous materials ${ }^{5}$. The dimensions of the mineral fibers were measured using transmission electronic microscopy or scanning electronic microscopy (Table 1) ${ }^{2,5,6)}$.

\section{Intratracheal instillation}

Male Wistar rats (10 weeks old) were used in this study, and each group of 5 rats was intratracheally instilled with saline or mineral fibers suspended in saline $(2 \mathrm{mg}$ of crocidolite, chrysotile, TW, or RF1), and was housed in clean 


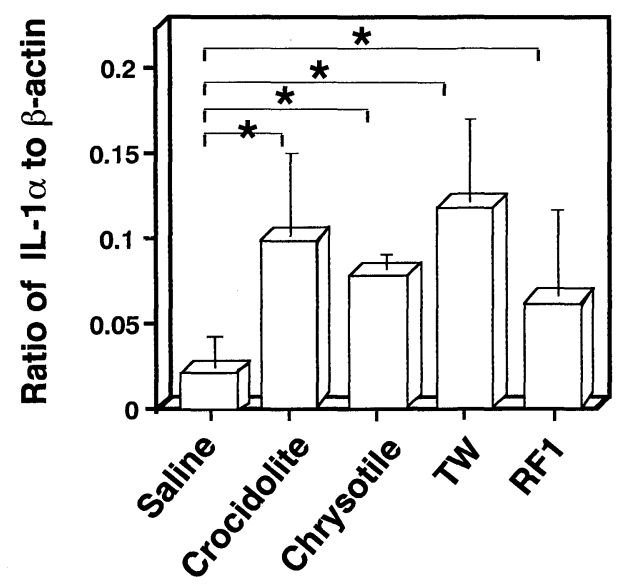

Fig. 2. Gene expression of IL-1 $\alpha$ in AMs exposed to man-made mineral fibers.

TW: potassium octatitanate whisker, RF1; alumina silicate ceramic fibers. Results are expressed in ratio of IL- $1 \alpha$ to $\beta$-actin. ${ }^{*} \mathrm{P}<0.05$.

air for 4 weeks. Bronchoalveolar lavage (BAL) was performed, and the recovered cells were plated on tissue culture plates. They were allowed to attach for 1 hour at $37^{\circ} \mathrm{C}$ with RPMI- 1640 medium containing $10 \%$ fetal bovine serum ${ }^{7}$. Adherent AMs were adjusted to a final concentration of $1 \times 10 \% / \mathrm{ml}$ and were stimulated with $10 \mu \mathrm{g} / \mathrm{ml}$ of lipopolysaccharide (LPS) (Escherichia coli, Sigma, St. Louis, Mo.). The AMs were cultured for 2 or 6 hours on cell culture plates at $37^{\circ} \mathrm{C}$ in a $\mathrm{CO}_{2}$ incubator.

Then, mRNA in the AMs was extracted using a Quick Prep $^{R}$ kit (Pharmacia Biotech, Uppsala, Sweden). The gene expression of IL-1 $\alpha, \mathrm{TNF} \alpha$ and iNOS in AMs stimulated with LPS for 2 hours and IL-6 in them for 6 hours was assessed using RT-PCR.

\section{cDNA synthesis, PCR and its quantification}

RNA was used for the synthesis of single-strand cDNA using Moloney murine leukemia virus-derived reverse transcriptase (Perkin Elmer, Norwalk, Connecticut). An equal amount of cDNA from each sample was amplified by specific primers for rat IL- $1 \alpha$, TNF $\alpha$, IL- 6 and iNOS. The amplification was performed using a thermocycler (Astech, Japan) under the following conditions: denaturation at $94^{\circ} \mathrm{C}$ for $45 \mathrm{sec}$, annealing at $60^{\circ} \mathrm{C}$ for $45 \mathrm{sec}$, and extension at $72^{\circ} \mathrm{C}$ for $2 \mathrm{~min}$. $\beta$-actin was co-amplified as an internal standard to quantify PCR amplification of mRNA. The number of thermo-cycles used was selected to allow quantification without saturation ${ }^{8)}$.

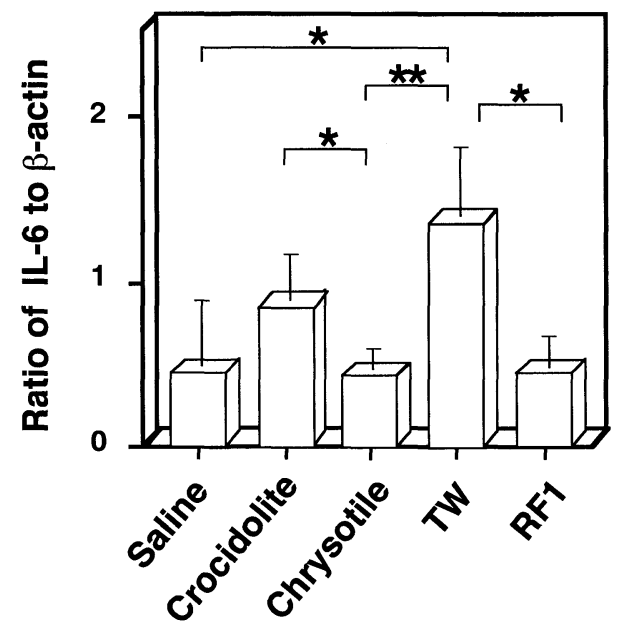

Fig. 3. Gene expression of IL-6 in AMs exposed to man-made mineral fibers.

TW: potassium octatitanate whisker, RF1; alumina silicate ceramic fibers. Results are expressed in ratio of IL-6 to $\beta$-actin. $* \mathrm{P}<0.05,{ }^{*} \mathrm{P}<0.01$.
Detection of the fragments amplified by the PCR was made by electrophoresis on a $2 \%$ agarose gel. PCR products were resolved by gel electrophoresis and visualized by ethidium bromide staining. The gel was photographed with Polaroid Type 665 positive/negative film (Polaroid Corporation, Cambridge, Massachusetts) under UV light at identical exposure and developing time. The bands of the positive film were scanned, and the density of each PCR product was measured using National Institutes of Health image 1.56 software (written by Wayne Rasband at NIH, Bethesda, Maryland). The ratio of each specific gene product to the $\beta$-actin product was used for the analysis.

\section{Statistical analysis}

Values were expressed as the mean \pm one standard deviation. The difference between values was assessed using a Mann-Whitney $U$ test. $P$ values of $<0.05$ were considered significant.

\section{Results}

\section{Gene expression of IL-1 $\alpha$ mRNA}

Fig. 2 shows the gene expression of IL-1 $\alpha$ mRNA in AMs induced by mineral fibers ${ }^{3}$. Exposure to each mineral fiber increased in the gene expression of IL- $1 \alpha$. The message levels of IL- $1 \alpha$ following mineral fibers-exposure was greatest in AMs exposed to TW or crocidolite, followed by those exposed to chrysotile and RF1. 


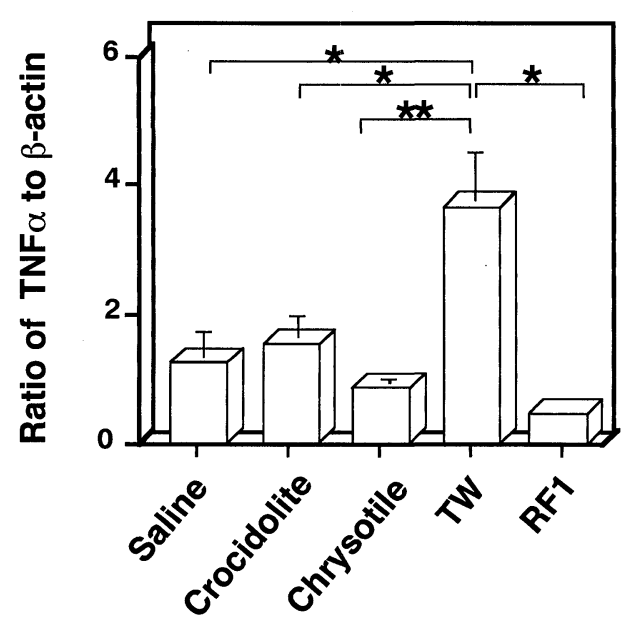

Fig. 4. Gene expression of TNF $\alpha$ in AMs exposed to man-made mineral fibers.

TW: potassium octatitanate whisker, RF1; alumina silicate ceramic fibers. Results are expressed in ratio of $\mathrm{TNF} \alpha$ to $\beta$-actin. $* \mathrm{P}<0.05, * * \mathrm{P}<0.01$.

\section{Gene expression of IL-6 $m R N A$}

The result of the gene expression of IL-6 mRNA was similar to that of IL-1 $\alpha$ (Fig. 3). Exposure to TW and crocidolite elevated the expression of IL-6, however exposure to chrysotile and RF1 did not.

\section{Gene expression of TNF $\alpha$ mRNA}

Compared to the saline group, the level of TNF $\alpha$ mRNA was significantly increased in animals exposed to TW, and was not increased in animals exposed to crocidolite, chrysotile or RF1 (Fig. 4).

\section{Gene expression of iNOS $m R N A$}

Transcripts for iNOS were increased in rats exposed to crocidolite (Fig. 5); however, other mineral fibers did not change the iNOS mRNA level.

\section{Discussion}

The recovery time was set 4 weeks after tracheal instillation of mineral fibers. Other reports of inhalation studies have shown that nonspecific responses at the acute phase were seen after the intratracheal instillation ${ }^{9}{ }^{10)}$, and that saline injection by BAL caused a neutrophil recruitment in the lower respiratory tract 72 hours later. We previously reported that the intratracheal injection of saline as well as of chrysotile elevated the gene expression of TNF $\alpha$ mRNA in AMs at 3 days and 1 week after intratracheal instillation, and that this

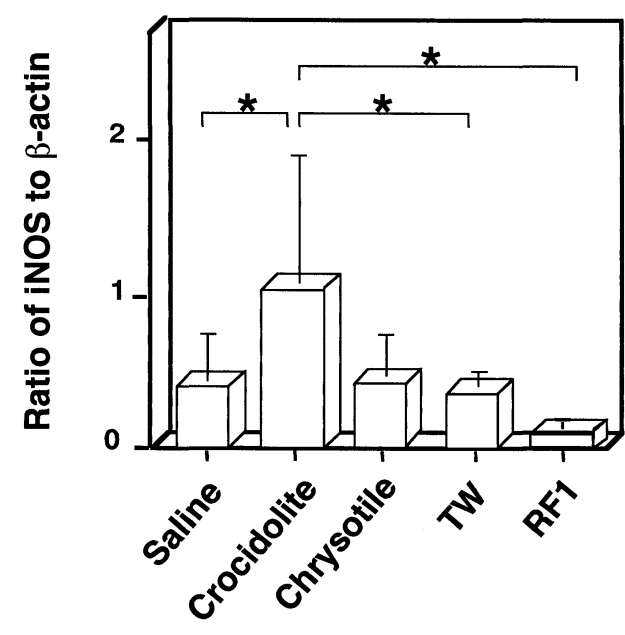

Fig. 5. Gene expression of iNOS in AMs exposed to man-made mineral fibers.

TW: potassium octatitanate whisker, RF1; alumina silicate ceramic fibers. Results are expressed in ratio of iNOS to $\beta$-actin. ${ }^{*} \mathrm{P}<0.05$.

saline-induced response was not observed 4 weeks after exposure ${ }^{2}$. To avoid the initial influence of acute response, we set the recovery time for four weeks in this experiment.

In this experiment, the expression of IL-1 $\alpha$ mRNA induced by mineral fiber-exposure was greatest in TW, crocidolite, chrysotile and RF1-instilled rat AMs, in that order. Since inhalation of crocidolite causes fibrosis and carcinoma in the lung, crocidolite is known to be representative of mineral fibers which possess a high pathologic potential ${ }^{1}$. It has been reported that TW produces marked pulmonary fibrosis in rats with long-term inhalation ${ }^{11)}$. We also reported that both TW and crocidolite stimulated the production of TNF in AMs in vitro ${ }^{2)}$ and induced pulmonary fibrosis in rats in a long term inhalation study ${ }^{12}$. These results suggest that TW might have a high toxic potential, similar to crocidolite. Although chrysotile has also been shown to be capable of inducing lung cancer, fibrosis and mesothelioma, it is one of the least toxic asbestos fibers ${ }^{13)}$. In this experiment, chrysotile did not increase in the gene expression of cytokines except IL-1 $\alpha$. Some investigators have shown that inhalation of ceramic fibers causes pulmonary fibrosis and carcinoma in animal studies ${ }^{12,14,15)}$, but there are others which show that ceramic fibers do not induce these changes. We previously reported that long-term inhalation of rats to RF1 did not cause any pathological changes ${ }^{10)}$, and that RF1 has a weak cytotoxicity in vitro ${ }^{2)}$. Therefore, the refractory fibers (RF1) used in this experiment may not have a high toxicity. Taken together, these data showed that TW and crocidolite 
with a high toxic potential increased in gene expression of IL- $1 \alpha$, suggesting that IL- $1 \alpha$ levels are in accord with the pathologic potential of mineral fibers.

This study shows that IL-6 levels follow a trend similar to IL- $1 \alpha$ levels. Recent papers have shown that IL- 6 levels were increased in the bronchoalveolar lavage fluid (BALF) of patients with idiopathic pulmonary disease, as well as in patients with pneumoconiosis ${ }^{16)}$. IL-6 is thought to be one of the key cytokines in the process of pulmonary fibrosis, and IL-1 works together with IL-6.

Compared to these other cytokines, message levels of TNF $\alpha$ were not elevated by crocidolite. In our previous report $^{3)}$ the levels of TNF $\alpha$ mRNA corresponded to the number of neutrophils in the BALF during the nonspecific acute phase response. Therefore, TNF may contribute to more acute phase of lung injury. In this experiment, exposure to TW did not elevate levels of iNOS mRNA in AMs. Oxidants released by inflammatory cells are thought to play a key role in lung injury of pulmonary fibrosis ${ }^{16}$. Crocidolite is known to cause lung injury through free radical formation including nitric oxide radical (NO) and peroxynitrite anion $\left(\mathrm{ONOO}^{-}\right)^{17}$. iNOS may not be involved in the lung injury induced by TW even though reactive species of free radicals are present.

\section{Summary}

The gene expression of IL-1 $\alpha$, TNF $\alpha$, IL- 6 and iNOS was examined by RT-PCR in rat AMs following mineral fiber exposure. The increase in expression of IL- $1 \alpha$ and IL-6 mRNA by mineral fibers was greatest in TW, crocidolite, chrysotile and RF1 instilled rats in that order. The increased expression of IL- $1 \alpha$ and IL- 6 by mineral fibers may provide a good indicator for the risk assessment of mineral fibers.

\section{Acknowledgments}

We thank Ms. M. Tsunoda for technical assistance with some of the experiments. This work was partly supported by the Fukuoka Cancer Society and Uehara Memorial Foundation.

\section{References}

1) Becklake MR (1976) Asbestos-related diseases of the lung and other organs: their epidemiology and implications for clinical practice. Am Rev Respir Dis 114, 187-227.
2) Fujino A, Hori H, Higashi T, Morimoto Y, Tanaka I, Kaji H (1995) In-vitro biological study evaluate the toxic potentials of fibrous materials. Int $J$ Occup Envirion Health 1, 21-8.

3) Tsuda $T$, Morimoto $Y$, Yamato $H$, Nakamura $H$, Hori H, Nagata N, Kido M, Higashi T, Tanaka I (1997) Effects of mineral fibers on the expression of genes whose product may play a role in fiber pathogenesis. Environ Health Perspect 105 (Suppl 5), 1173-8.

4) Mossman BT, Churg A. (1998) Mechanisms in the pathogenesis of asbestosis and silicosis. Am J Respir Crit Care Med 157, 1666-80.

5) Kohyama N, Tanaka I, Tomita M, Kudo M, Shinohara $Y$ (1997) Preparation and characteristics of standard reference samples of fibrous minerals for biological experiments. Industrial Health 35, 415-32.

6) Kohyama N, Shinohara Y, Suzuki Y (1996) Mineral phases and some reexamined characteristics of the international union against cancer standard asbestos samples. Am J Ind Med 30, 515-28.

7) Jordana M, Richards C, Irving LB, Gauldie J (1988) Spontaneous in vitro release of alveolar macrophage cytokines after the intratracheal instillation of bleomycin in rats. Am Rev Respir Dis 137, 1135-40.

8) Weisner RJ, Zac R (1991) Quantative approaches for studying gene expression. Am J Physiol 260, L17988.

9) Von Essen SG, Robbins RA, Spurzem JR, Thompson AB, McGranaghan SS (1991) Bronchoscopy with bronchoalveoar lavage causes neutrophil recuitment to the lower respiratory tract. Am Rev Respir Dis 144, 848-54.

10) Adamson IYR, Bowden DH (1984) Role of polymorphonuclear leukocytes in silica-induced pulmonary fibrosis. Am J Pathol 117, 37-43.

11) Lee KP, Barras CE, Griffith FD, Waritz RS (1981) Pulmonary response and transmigration of inorganic fibers by inhalation exposure. Am J Pathol 102, 314 23.

12) Tsuda $T$, Yamato $H$, Morimoto $Y$, Oyabu $T$, Ishimatsu S, Hori H, Kasai T, Kido M, Higashi T, Tanaka I (1998) One year inhalation study of man-made fibers. In: Advances in the prevention of occupational respiratory diseases. eds. by Chiyotani K, Hosoda Y, Aizawa Y, 596-600, Elsevier Science B.V. Press.

13) Ghio AJ, Kennedy TP, Stonehuerner JG, Crumbliss AL, Hoidal JR (1994) DNA strand breaks following in vitro exposure to asbestos increase with surface-complexed 
[Fe3+]. Arch Biochem Biophys 311, 13-8.

14) Davis JMG, Addison J, Bolton RE, Donaldson $K$, Jones AD, Wright A (1984) The pathogenic effects of fibrous ceramic aluminium silicate glass administered to rats by inhalation and peritoneal injection. In: Biological effects of man-made mineral fibers. Proceedings of a WHO/IARC Conference, Volume 2, 303-22, Copenhagen, Denmark, April 20-22, WHO Regional Office for Europe.

15) Hesterberg TW, Mast R, McConnell EE (1991) Chronic inhalation toxicity of refractory ceramic fibers in Syrian hamsters, mechanisms in fibre carcinogenesis. eds. by RC Brown et al., Plenum Press, New York.

16) Vanhee D, Gosset P, Boitelle A, Wallaert B, Tonnel $\mathrm{AB}$ (1995) Cytokines and cytokine network in silicosis and coal workers' pneumoconiosis. Eur Respir J 8, 834 42.

17) Holly JA, Janssen YMW, Mossman BT, Taatjes DJ (1992) Increased manganese superoxide dismutase protein in type 2 epithelial cells of rat lungs after inhalation of crocidolite asbestos or cristobalite silica. Am J Pathol 141, 475-85. 